\title{
Antimicrobial and cytotoxic properties of selected medicinal plants from Kavrepalanchowk, Nepal
}

\author{
R. Gyawali ${ }^{*}$, S. Adhikari ${ }^{1}$, S. Gautam ${ }^{1}$, P. Guragain ${ }^{1}$, S. Pokharel ${ }^{1}$, N. Pradhan ${ }^{1}$, \\ S. Sijapati ${ }^{1}$ and T. M. Shrestha ${ }^{1}$
}

\begin{abstract}
Antibacterial properties of Nepalese plant species - Myrica esculenta, Mahonia nepaulensis, Madhuca longifolia and Schima wallichii were evaluated on human pathogenic microorganisms: Salmonella typhi, Staphylococcus aureus and Escherichia coli. The plants were found to possess phytochemicals- saponins, glacosides, flavonoids, tannins and alkaloids. Methanolic extract from these plants showed antimicrobial activity against tested organisms. Similarly, Brine shrimp lethality test of extracts showed the LC50 values of $15.4 \mathrm{ppm}, 136.4 \mathrm{ppm}, 76.9$ ppm and $76.0 \mathrm{ppm}$ for $M$. esculenta, $M$. nepaulensis, M. longifolia and S. wallichii respectively, which suggests that these plants are less toxic to human consumption for drug purpose.
\end{abstract}

Key words: Nepalese plants, phytochemicals, antimicrobial and cytotoxic activities, human pathogens

$\mathrm{T}_{\mathrm{h}}^{\mathrm{h}}$ he history of medicine and medicinal plants in Nepal can be traced back to the Vedic Period where Nepal Himalaya has been mentioned as a sacred heaven of potent medicinal and aromatic plants. The original "Sanskrit Nighantu," written on palm leaves in Newari script and Sanskrit verses during Mandeva Era 301 (879 AD), is said to be the oldest of these books. The usage of the plants as subsistence for folk therapies was largely influenced from traditional medicinal health care systems mainly for treating or preventing various ailments. A major part of total population in developing countries uses folklore medicine obtained from plant resources (Fabricant and Farnsworth, 2001). Medicinal plant usage forms the backbone in many rural communities for treating ailments with varying severity (Wyk et al., 1997). The utilization of medicinal plant remedies in preventing or curing various ailments were the sole source of ensuring human welfare until the development of chemistry and organic compound synthesis in the 19th century (Kong et al., 2003).

The research on biologically active compounds from natural sources has always been of great interest for scientists looking for new sources of useful drugs against infectious diseases. In recent years, interest to evaluate plants possessing antibacterial activity for various microbes is growing. This is because of the increase in the resistance by microorganisms to new antibiotics as compared to the past. In general, bacteria have the genetic ability to transmit and acquire resistance to drugs which are utilized as therapeutic agents (Gislene et al., 2000). Plant parts such as fruits, leaves, stems and barks are used in traditional medicinal practice for curing cough and cold, tonsillitis, headache, malarial fever and neck pain; to reduce blood pressure, chest pains, lung diseases, bronchitis and respiratory diseases; and for treatment of animals affected by different kinds of insects, scabies and wounds (Gyawali et al., 2008). Several medicinal plants have been screened to identify the possible natural antibacterial agents from medicinal plants (Gyawali et al., 2013, 2014). Myrica esculenta Buch-Ham ex D. Don (Myricaceae) bark is useful for cough, asthma, sinusitis and chronic bronchitis, diarrhea and dysentery (Baral and Kurmi, 2006; Watanabe et al., 2005). Mahonia nepaulensis DC (Berberidaceae) bark juice is traditionally used in many communities to treat infections and wounds. The barks of Madhuca longifolia (J. Koeing ex L) J.F. Macbr (Sapotaceae) are said to possess antibacterial

\footnotetext{
${ }^{1}$ Department of Pharmacy, Kathmandu University (KU), Dhulikhel, Kavrepalanchowk, Nepal,

* Email: gyawali@ku.edu.np
} 
activity, bleeding and spongy gums. The barks of Schima wallichii (DC) Korth (Theaceae) are used as an antiseptic for cuts and wounds, vermicide, mechanical irritant and to cure gonorrhea. The barks juice is given to animals infested with liver flukes. Decoction of barks is good for fever and effective against head lice (Gurung, 2002).

Due to specific climatic and geographical conditions of the Himalaya, medicinal plants offer greater possibilities of having novel antimicrobial property with large quantities of the active compounds. Based on the ethno-pharmacological information, the authors have recently documented several medicinal plants found in the various geographical locations of Nepal so as to evaluate the phytochemical profiles and efficacy of traditional medicines. All these conditions were taken into account while conducting the research aimed to assess phytochemical and biological properties of Nepalese medicinal plants.

\section{Materials and methods}

\section{Study area}

The plant materials were collected from 1400 to $1600 \mathrm{~m}$ altitudes within Khopasi Village Development Committee of Kavrepalanchowk District of Central Nepal.

\section{Plant materials}

Some barks of $M$. esculenta, M. longifolia, $M$. nepaulensis and $S$. wallichii were collected as samples for the purpose of this study. Each sample was pulverized by using home blender, and the powdered sample was initially soaked in methanol for 7 days with occasional shaking. After 7 days, the mixture was filtered, and the process was repeated two times more. The filtrates were combined and the methanol was evaporated from the extracts.

\section{Phytochemical screening}

The crude methanolic extracts of the barks of different plants were screened to detect the presence of phytochemicals, as per the Standard Screening Procedure (Trease and Evans, 1996).

\section{Antimicrobial assays}

In this study, strains of human pathogenic microorganisms viz. Salmonella typhi, Staphylococcus aureus and Escherichia coli, collected from Dhulikhel Hospital, Kathmandu
University and Teaching Hospital, were used to investigate the antimicrobial potential of the extracts with the help of disk diffusion method. Required amount of bark extract of all four plants were dissolved in methanol to give methanolic extract solution of concentrations of $0 \%, 3 \%$, $6 \%$ and $9 \%$; sterile, $6 \mathrm{~mm}$ diameter grade I Whatmans filter paper discs were impregnated with the already prepared methanolic solution. Ciprofloxacin $(30 \mu \mathrm{g})$ was used as positive control while Methanol $(30 \mu \mathrm{l})$ was used as negative control. Triplicates of each extract were impregnated in $6 \mathrm{~mm}$ diameter disc. To evaporate the methanolic residue from discs, they were placed over the water bath for 1 hour. Each microorganism, at a concentration of $1.5 \times 106$ cells $/ \mathrm{ml}$ (adjusted to the $0.5 \mathrm{McF}$ arland turbidity standards), was inoculated on the surface of the respective media. After holding the plates at room temperature for one hour to allow diffusion of the test samples into the agar, they were incubated at $37^{\circ} \mathrm{C}$ for 24 hours. The results thus obtained were recorded by measuring the zones of growth inhibition around the disc, and presented as the arithmetic average. Inhibition zone values were corrected i.e. the disk diameter was subtracted from the value of the inhibition zone. Overall, cultured microorganisms with zone of inhibition equal to or greater than $7 \mathrm{~mm}$ were considered susceptible to the samples tested.

\section{Brine shrimp lethality test}

Methanolic extract of the samples were evaluated for lethality to Brine shrimp larvae (A. salina Leach) according to the published procedure (Meyer et al., 1982). Brine shrimp eggs were suspended for 48 hours in a conical flask containing $300 \mathrm{ml}$. of artificial seawater for hatching (the eggs). The flasks were well aerated with the aid of an air pump, and kept in a water bath at $29-30^{\circ} \mathrm{C}$. The extracts were dissolved in $1 \%$ aqueous DMSO, and then in sea water to obtain a concentration of $500 \mathrm{ppm}, 250 \mathrm{ppm}, 100$ ppm, $50 \mathrm{ppm}, 25 \mathrm{ppm}$ and $10 \mathrm{ppm}$. An aliquot of each concentration $(1 \mathrm{ml})$ was transferred, in triplicate, into clean sterile vials with pipette, and aerated seawater $(9 \mathrm{ml})$ was added. Ten Brine shrimp nauplii were transferred to each vial. Thymol $1 \%$ aqueous solution and $1 \%$ DMSO in seawater were used as positive and negative controls, respectively. After 24 hours, the numbers of survivors were counted, and the mortality percentage was calculated. The lethal 
concentration for $50 \%$ mortality after 24 hours of expo-sure, the chronic $\mathrm{LC}_{50}$ and $95 \%$ confidence intervals were determined using the Probit method (Finney, 1971) as the measure of toxicity of the extract or fractions. The extracts were considered as toxic unless the $\mathrm{LC}_{50}$ was found to be less than $10 \mathrm{ug} / \mathrm{ml}$ (Setzer et al., 2001).

\section{Results and discussion}

The randomly selected barks of the plants subject to phytochemical screenings were found to contain different compounds viz. alkaloids, tannin, saponins, flavonoids and glycosides. The methanolic extract of $M$. esculenta barks exhibited antimicrobial activity against all the test-microorganisms. The methanolic extract of M. esculenta barks exhibited the highest activity against $E$. coli with the mean growth inhibition zones of $10.33 \pm 1.52 \mathrm{~mm}, 12.33 \pm 1.15 \mathrm{~mm}$ and $15 \pm 1 \mathrm{~mm}$ at $3 \%, 6 \%$ and $9 \%$ concentrations respectively (Table 1). Similarly, it exhibited the highest significant antibacterial activity against Salmonella typhi with the mean inhibition zone of $9.33 \pm 0.57 \mathrm{~mm}$ at $9 \%$ concentration.

The methanolic extract of M. nepaulensis barks exhibited maximum effect against Staphylococcus aureus with the mean growth inhibition zones of $10.33 \pm 1.52 \mathrm{~mm}$ and $12.67 \pm 1.53 \mathrm{~mm}$ at $6 \%$ and $9 \%$ concentrations respectively (Table 1). The methanolic extract of $M$. nepaulensis barks showed a broad spectrum of antimicrobial activity which might be due to the presence of alkaloids and flavonoids.
The methanolic extract of the $S$. wallichii barks exhibited highest activity against $S$. aureus and E. coli with $8.67 \pm 0.57 \mathrm{~mm}$ and $10.33 \pm 0.57 \mathrm{~mm}$ mean growth inhibition zones respectively at $9 \%$ concentration (Table 1). The hydroalcoholic extract of the $S$. wallichii bark has been found to exhibit the highest sensitivity against $E$. coli while the least activity against the selected Gram positive strains (Dewanjee et al., 2008). S. aureus, being Gram positive, supports our results.

The methanolic extract of $M$. longifolia bark also revealed its antibacterial property. It exhibited maximum effect with the mean growth inhibition zone of $12.67 \pm 2.08 \mathrm{~mm}$ and $15 \pm 1 \mathrm{~mm}$ against $E$. coli at $6 \%$ and $9 \%$ concentrations respectively (Table 1). The barks of $M$. longifolia chiefly contain Oleanolic acid, caprylate, lepeolacetate, $\alpha$-amyrin acetate, erythrodiolmonocaprylate, betulinic acid and $\alpha$-spinasterol compounds (Khare, 2007). The antimicrobial property of $M$. longifolia bark found in our study could be due to the effects of lepeolacetate, $\alpha$-amyrin acetate, erythrodiolmonocaprylate, betulinic acid, $\alpha$-spinasterol and/or other methanol soluble constituents. Lupeol acetate belongs to lupane type triterpenes, and was reported to have antimicrobial activity (Prachayasittikul et al., 2010).

Based on the Brine shrimp bioassay analysis, the $\mathrm{LC}_{50}$ value of the bark of $M$. esculenta plant was found to be $15.5 \mathrm{ppm}$ (Table 2). Similarly, the $\mathrm{LC}_{50}$ values of the barks of $M$. nepaulensis, $M$. longifolia and $S$. wallichii plants were found to be

Table 1: Mean growth inhibition zones $(\mathrm{mm})$ of the barks of different plants

\begin{tabular}{|c|c|c|c|c|c|c|c|c|c|}
\hline \multirow{3}{*}{$\begin{array}{l}\text { Plant name/ } \\
\text { Std. drug }\end{array}$} & \multicolumn{3}{|c|}{ Staphylococcus aureus } & \multicolumn{3}{|c|}{ Escherichia coli } & \multicolumn{3}{|c|}{ Salmonella typhi } \\
\hline & \multicolumn{3}{|c|}{ Concentration of extract } & \multicolumn{3}{|c|}{ Concentration of extract } & \multicolumn{3}{|c|}{ Concentration of extract } \\
\hline & $3 \%$ & $6 \%$ & $9 \%$ & $3 \%$ & $6 \%$ & $9 \%$ & $3 \%$ & $6 \%$ & $9 \%$ \\
\hline $\begin{array}{l}\text { Myrica } \\
\text { esculenta }\end{array}$ & $5 \pm 0$ & $5 \pm 1$ & $7.33 \pm 1.52$ & $10.33 \pm 1.52$ & $12.33 \pm 1.15$ & $15 \pm 1$ & $4.33 \pm 1.15$ & $6.67 \pm 0.57$ & $9.33 \pm 0.57$ \\
\hline $\begin{array}{l}\text { Madhuca } \\
\text { longifolia }\end{array}$ & $5.67 \pm 1.15$ & $7.33 \pm 0.57$ & $9.33 \pm 0.57$ & $8 \pm 2$ & $12.67 \pm 2.08$ & $15 \pm 1$ & $6 \pm 1$ & $7.33 \pm 1.15$ & $8.67 \pm 1.52$ \\
\hline $\begin{array}{l}\text { Mahonia } \\
\text { nepaulensis }\end{array}$ & $7 \pm 3$ & $10.33 \pm 1.52$ & $12.67 \pm 1.52$ & 0 & 0 & $7.67 \pm 0.57$ & 0 & $2.33 \pm 1.15$ & $5 \pm 1$ \\
\hline $\begin{array}{l}\text { Schima } \\
\text { wallichii }\end{array}$ & $3 \pm 1$ & $5.33 \pm 0.57$ & $8.67 \pm 0.57$ & 2. $67 \pm 0.57$ & $6.67 \pm 0.57$ & $10.33 \pm 0.57$ & 0 & 0 & 0 \\
\hline $\begin{array}{l}\text { Ciprofloxacin, } \\
30 \mathrm{mcg}\end{array}$ & & $25.67 \pm 2.83$ & & & $35.67 \pm 1.10$ & & & $18.29 \pm 1.98$ & \\
\hline $\begin{array}{l}\text { Methanol, } \\
30 \mu \mathrm{l}\end{array}$ & & 0 & & & 0 & & & 0 & \\
\hline
\end{tabular}


Table 2: Brine shrimp bioassay results of methanolic extract of some Nepalese medicinal plant barks

\begin{tabular}{lrrr}
\hline \multirow{2}{*}{ Plant } & Lethal concentration, & \multicolumn{2}{c}{ 95\% Confidence interval } \\
\cline { 3 - 4 } $\mathbf{L C}_{\mathbf{5 0}} \mathbf{( p p m )}$ & 15.452 & Lower limit (ppm) & Upper limit (ppm) \\
\hline Myrica esculenta & 136.458 & 3.388 & 70.631 \\
Mahonia nepaulensis & 76.913 & 6.324 & 490.907 \\
Madhuca longifolia & 76.032 & 5.272 & 1119.438 \\
Schima wallichii & 2.864 & 2013.724 \\
\hline
\end{tabular}

Table 3 : Phytochemical screening of different plant barks (+ = presence, $--=$ absent)

\begin{tabular}{lccccc}
\hline Plants & Saponins & Glycosides & Tannins & Alkaloids & Flavonoids \\
\hline Myrica esculenta & ++ & ++ & ++ & -- & ++ \\
Madhuca longifolia & ++ & ++ & ++ & -- & ++ \\
Mahonia nepaulensis & -- & -- & -- & ++ & ++ \\
Schima wallichii & ++ & ++ & -- & -- & ++ \\
\hline
\end{tabular}

$136.5 \mathrm{ppm}, 76.9 \mathrm{ppm}$ and $76.0 \mathrm{ppm}$ respectively. This indicates that the bark of $M$. esculenta plant is moderately toxic, the barks of $M$. longifolia and $S$. wallichii plants are mildly toxic and the bark of M. nepaulensis plant is non-toxic. For the purpose, the results were compared with the available previous results: highly toxic plants (having $\mathrm{LC}_{50}<1.0 \mathrm{ppm}$ ); toxic plants (having $\mathrm{LC}_{50}$ of 1.0-10.0 ppm); moderately toxic plants (having $\mathrm{LC}_{50}$ of $10.0-30.0 \mathrm{ppm}$ ); mildly toxic plants (having $\mathrm{LC}_{50}$ of $30-100 \mathrm{ppm}$ ) and nontoxic plants (having $\mathrm{LC}_{50}>100 \mathrm{ppm}$ ) (Meyer et al., 1982).

The barks of all the selected plants viz. $M$. esculenta, M. nepaulensis, $M$. longifolia and $S$. wallichii were found to possess flavonoids, an important antimicrobial phytochemical (Table 3). The barks of M. esculenta and M. longifolia plants were found to possess saponins, glycosides and tannins too. Similarly, the bark of $M$. nepaulensis plant was found to possess alkaloids too while that of $S$. wallichii was found to possess saponins and glycosides too.

\section{Conclusion}

The analysis of randomly selected Nepalese medicinal plants indicated that most of the plants are rich in antimicrobial phytochemicals. Methanolic extracts from the barks of these plants showed antimicrobial activity against human pathogenic microorganisms. So, attention to these medicinal plants can be drawn for herbo- therapeutic treatment or antimicrobial plant principles in the case of infection by selected microorganisms.

\section{Acknowledgements}

This study was conducted with the support of the Kathmandu University (KU). The authors would like to particularly acknowledge, Head of the Department of Pharmacy, KU for her generous support to accomplish this study.

\section{References}

Baral, S. R. and Kurmi, P. P. 2006. Compendium of Medicinal Plants in Nepal. Rachana Sharma Publishers, Kathmandu, Nepal.

Dewanjee, S., Maiti, A., Majumdar, R., Majumdar, A. and Mandal, S. C. 2008. Evaluation of antimicrobial activity of hydroalcoholic extract of Schima wallichii bark. Pharmacology online 1: 523-528.

Fabricant, D. S. and Farnsworth, N. R. 2001. The value of plants used in traditional medicine for drug discovery. Environmental Health Perspective 109: 69-75.

Finney, D. J. 1971. Probit Analysis. 3rd edition. Cambridge University Press, Cambridge, UK.

Gislene, G. F., Locatelli, N. J., Paulo, C. F. and Giuliana, L. S. 2000. Antibacterial activity of plant extracts and phytochemicals on antibiotic resistant bacteria. Brazilian Journal 
of Microbiology 31: 247-256.

Gyawali, R., Jnawali, D. and Kim, K. S. 2008. Phytochemical screening of some species of Nepalese medicinal plants. In Medicinal Plants in Nepal: An Anthology of Contemporary Research (eds) Jha, P. K., Karmacharya, S. B., Chhetri, M. K., Thapa, C. B. and Shrestha, B. B. Ecological Society (ECOS), Nepal, 43-49.

Gyawali, R., Bhandari, J., Amatya, S., Piya, E., Pradhan, U. L., Paudyal, R., Shrestha, R. and Shrestha, T. M. 2013. Antibacterial and cytotoxic activities of high altitude essential oils from Nepalese Himalaya. Journal of Medicinal Plant Research 7 (13): 738-743.

Gyawali, R., Dahal, B., Gautam, R., Shrestha, S., Joshi, S., Luitel, A. and Khanal, D. 2014. Phytochemical studies traditional medicinal plants of Nepal and their formulations. International Journal of Biology, Pharmacy and Allied Sciences 3 (2):189-203.

Gurung, B. 2002. The Medicinal Plants of the Sikkim Himalaya. 1st edition (ed) Gurung, J. B. Maples, Chakung, West Sikkim, India.

Khare, C.P. 2007. Indian Medicinal Plants: An Illustrated Dictionary. Springer Science, New York, USA.

Kong, J. M., Goh, N. K., Chia, L. S. and Chia, T. F. 2003. Recent advances in traditional plant drugs and orchids. Acta Pharmacologica Sinica 24 (1): 7-21.

Meyer, N., Ferrigni N. R. and Putnam, J. E. 1982. Brine shrimp: a convenient general bioassay for active plant constituents. Planta Medica 45: $31-32$.

Prachayasittikul, S., Sarabam, P., Cherdtrakulkiat, R., Ruchirawat, S. and Prachaysittikul, V. 2010. New bioactive triterpenoids and antimalarial activity of Diospyros rubra Lec. Experimental and Clinical Journal 9: 1-10.

Setzer, M. C., Setzer, W. N., Jackes, B. R., Gentry, G. A. and Moriarity, D. M. 2001. The medicinal value of tropical rainforest plants from Paluma, North Queensland, Australia. Pharmaceutical Biology 39: 67-78.

Trease G. E. and Evans W. C. 1996. Pharmacognosy. Alden Press, Oxford, UK.

Watanabe, T., Rajbhandari, K. R., Malla, K. J. and Yahara, S. 2005. A Handbook of Medicinal Plants of Nepal. Ayur Seed Life Environmental Institute, Japan.

Wyk, V. B. E., Van, O. B. and Gericke, N. 1997. Medicinal Plants of South Africa. 1st edition. Briza publications, Pretoria, South Africa. 